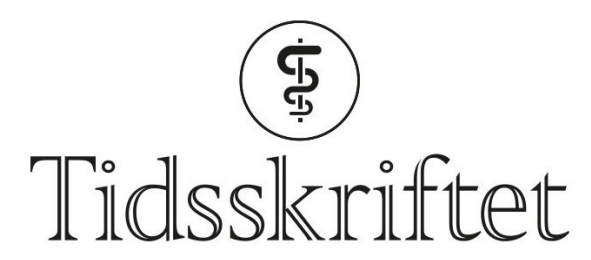

DEN NORSKE LEGEFORENING

\title{
Fødselsdepresjon er vanligere hos kvinner med multippel sklerose
}

FRA ANDRE TIDSSKRIFTER

SOFIE PAUS

Tidsskriftet

Også kvinner som fikk en MS-diagnose flere år etter fødselen, hadde økt risiko for fødselsdepresjon.

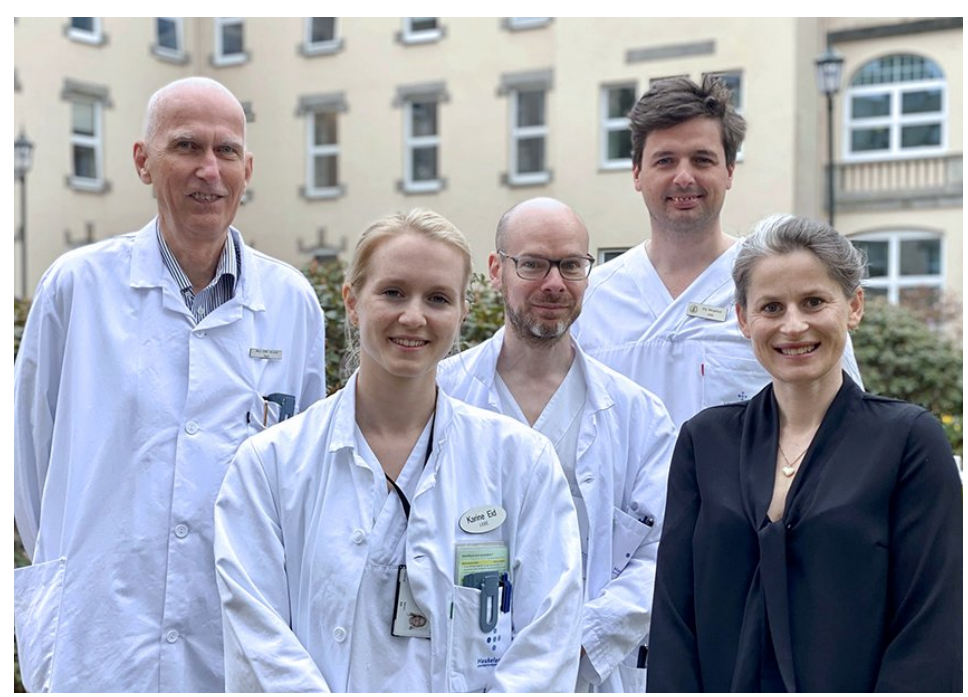

Fra venstre: Nils Erik Gilhus, Karine Eid, Øivind Torkildsen, Stig Wergeland og Marte-Helene Bjørk, alle medforfattere av artikkelen $i$ Neurology. Foto: Tale Bjerknes

Angst og depresjon er vanlig ved multippel sklerose (MS), men det er få studier om den psykiske helsen før og etter fødsel til kvinner med denne sykdommen.

I en norsk studie som nylig ble publisert i tidsskriftet Neurology, hadde nesten 115 ooo kvinner svart på spørsmål om angst og depresjon under graviditet i Den norske mor, far og barn-undersøkelsen (MoBa-undersøkelsen) (1). Kvinner med en MS-diagnose før graviditet hadde dobbel så høy risiko for depresjon i tredje trimester (justert oddsratio 2,0; 95 \% KI 1,2-3,1). Risikofaktorer var negative sosioøkonomiske faktorer, psykiatrisk sykdomshistorie og tidligere fysisk og/eller seksuelt misbruk. Kvinner diagnostisert med MS-sykdom i postpartumperioden hadde spesielt høy risiko for postpartumdepresjon. Kvinner med første MS-symptom innen fem år etter graviditet hadde økt risiko for både depresjon og angst under graviditet.

- Data fra MoBa-undersøkelsen koplet med norske registerdata gir oss et unikt studiedesign i internasjonal sammenheng, sier Karine Eid, som er stipendiat og studiens førsteforfatter. 
Så vidt vi vet, er vi de første som har funnet $\emptyset \mathrm{kt}$ risiko for svangerskapsdepresjon både hos kvinner som har multippel sklerose og hos kvinner som utvikler sykdommen senere, sier hun. De siste tiårene har det kommet effektiv behandling mot multippel sklerose, noe som har ført til at flere kvinner med denne sykdommen velger å få barn. Derfor er det viktig med oppdatert kunnskap om svangerskapsperioden.

Den $ø$ kte risikoen for svangerskapsdepresjon hos kvinner som får multippel sklerose senere, kan være relatert til prodromalperioden, dvs. en periode der sykdomsprosesser har begynt, men ikke gitt de klassiske symptomene. Andre studier har også vist økt risiko for depresjon og angst, særlig de siste fem årene før MS-sykdommen viser seg, noe denne studien bekrefter. Studien er den første som også viser $ø$ kt risiko for fødselsdepresjon. Studien er den første i et nyetablert samarbeid mellom Bergen Epilepsy Research Group (BERG) og Bergen MS-Forskningsgruppe. Bergen Epilepsy Research Group er en aktiv forskningsgruppe ved Nevrologisk avdeling, Haukeland universitetssjukehus, og Klinisk institutt 1, Universitetet i Bergen, og ledes av overlege og førsteamanuensis Marte-Helene Bjørk. Gruppen gjennomfører avanserte analyser av sammenkoblede registerdata og problemstillinger som gjelder gravide med epilepsi.

Bergen MS-Forskningsgruppe består av Nevro-SysMed, Nasjonal kompetansetjeneste for multippel sklerose, Norsk MS-register og biobank. Forskningsaktiviteten omfatter studier innen klinisk nevrologi, immunologi, epidemiologi, helseøkonomi, proteomikk og laboratorieforskning med dyremodeller. Gruppen er en del av Forskningssenter for klinisk behandling 2019-2027 og finansieres av Norges forskningsråd.

\section{LITTERATUR:}

1. Eid K, Torkildsen $\emptyset \mathrm{F}$, Aarseth J et al. Perinatal Depression and Anxiety in Women with Multiple Sclerosis: A Population-Based Cohort Study. Neurology 2021; 96: 10.1212/WNL.ooooooooooo12062. [PubMed][CrossRef]

Publisert: 21. juni 2021. Tidsskr Nor Legeforen. DOI: 10.4045/tidsskr.21.0434

(C) Tidsskrift for Den norske legeforening 2020. Lastet ned fra tidsskriftet.no 